$1-1-1910$

\title{
Three Snout Beetles That Attack Apples : Plum Curculio, Apple Curculio, Apple Weevil
}

Fred E. Brooks

Follow this and additional works at: https://researchrepository.wvu.edu/ wv_agricultural_and_forestry_experiment_station_bulletins

\section{Digital Commons Citation}

Brooks, Fred E., "Three Snout Beetles That Attack Apples : Plum Curculio, Apple Curculio, Apple Weevil" (1910). West Virginia Agricultural and Forestry Experiment Station Bulletins. 126.

https://researchrepository.wvu.edu/wv_agricultural_and_forestry_experiment_station_bulletins/126 @ WVU. It has been accepted for inclusion in West Virginia Agricultural and Forestry Experiment Station Bulletins by an authorized administrator of The Research Repository @WVU. For more information, please contact ian.harmon@mail.wvu.edu. 
West Virginia University Libraries

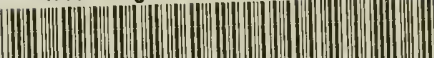

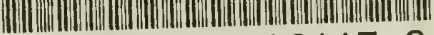

308021008961173 


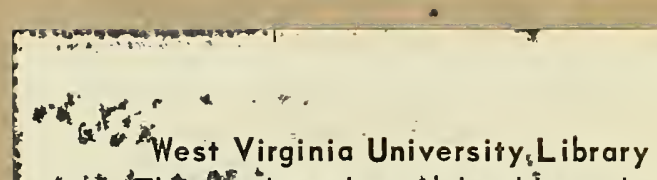

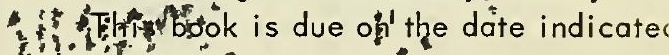

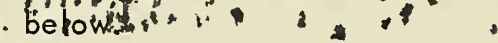

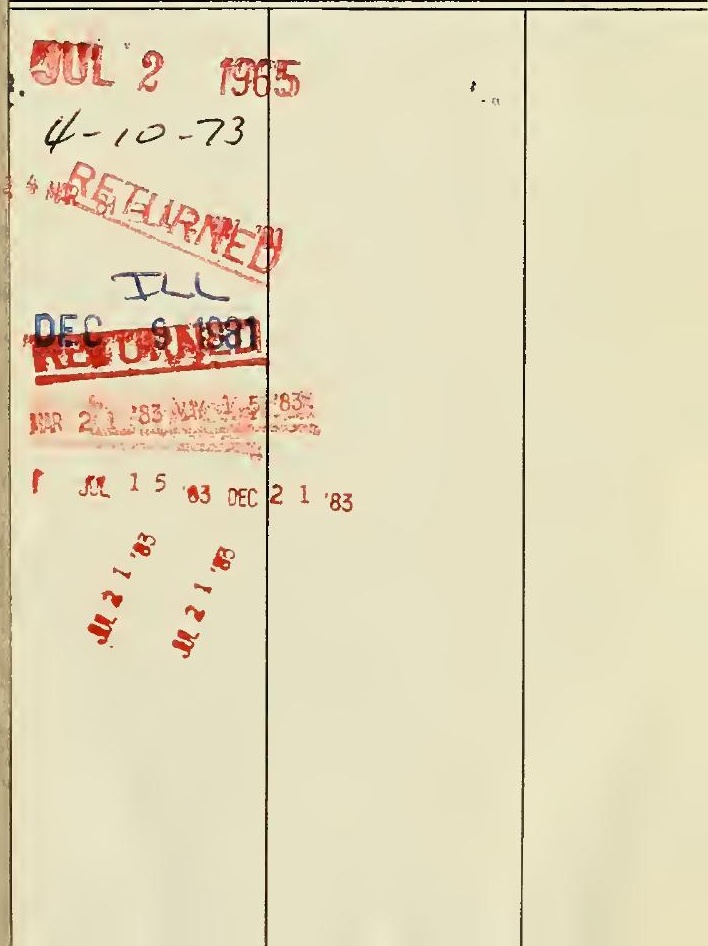



WEST VIRGINIA UNIVERSITY

AGRICULTURAL EXPERIMENT STATION

MORGANTOWN, W. VA.

\title{
Three Snout Beetles That Attack Apples
}

\author{
Plum Gurculio \\ Apple Curculio \\ Apple Weevil
}
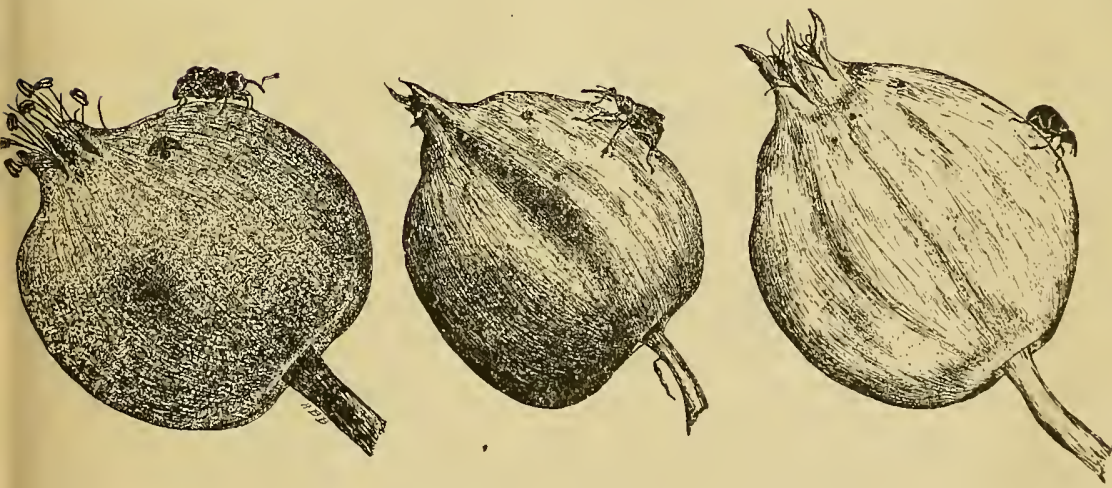

By Fred. E. BRoOKS

[The Bulietins and Reports of this Station will be mailed free to any citizen of West Virginia upon written application. Address Director of Agricultural Experiment Station, Morgantown, W. Va.] 
How. M. P. Shlwkey................ Charleston, W. Va. Hon. J. B. Finley .................. Parkersburg, W. Ta. Hon. George S. Latdley................ Charleston, W. Va. Hon. G. A. Мовтнсотт................. Huntington, W. Va. How. M. C. Lough..................... Fairmont, W. Va. President of the Board of Regents.............. P. Shatwkey Treasurer Thomas E. Hodges

\section{THE BOARD OF CONTROL.}

Hon. James F. Lakin .................. Charleston, W. Va. Hon. John A. Sheppard................ Charleston, W. Va. Hon. Thomas E. Hodges................ Charleston, W. Va.

\section{STATION STAFF.}

Janes H. Stewart, A. M......... Director and Agriculturist Bert H. Hite, M. S.............Vice Director and Chemist W. M. Munson, Рн. D.................. Horticulturist W. E. Rumsey, B. S. Agr................. Entomologist Nathan James Giddings, M. S.............. Bacteriologist Horace Atwood, M. S. AGR........... Assistant Agriculturist Fred E. BRooks................... Associate Entomologist Frank B. Kunst, A. B................ Assistant Chemist Chas. E. Weaklegr, JR................ Assistant Chemist J. H. Berghuts Krak................... Assistant Chemist

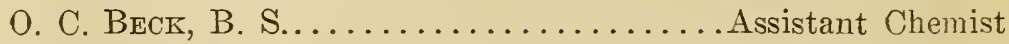
A. L. DACY, B. Sc............... Assistant Horticulturist

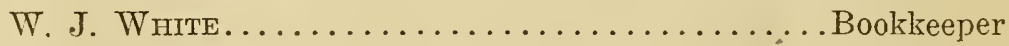
M. A. Stewart......................... Librarian

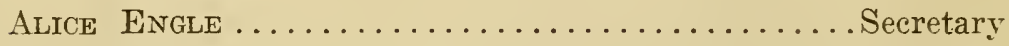

B. D. Whiте . . . . . . . . . . . . . . . . Herdsman Tнео. F. Ізивасн...................... Greenhouseman 
Digitized by the Internet Archive in 2010 with funding from

Lyrasis Members and Sloan Foundation 


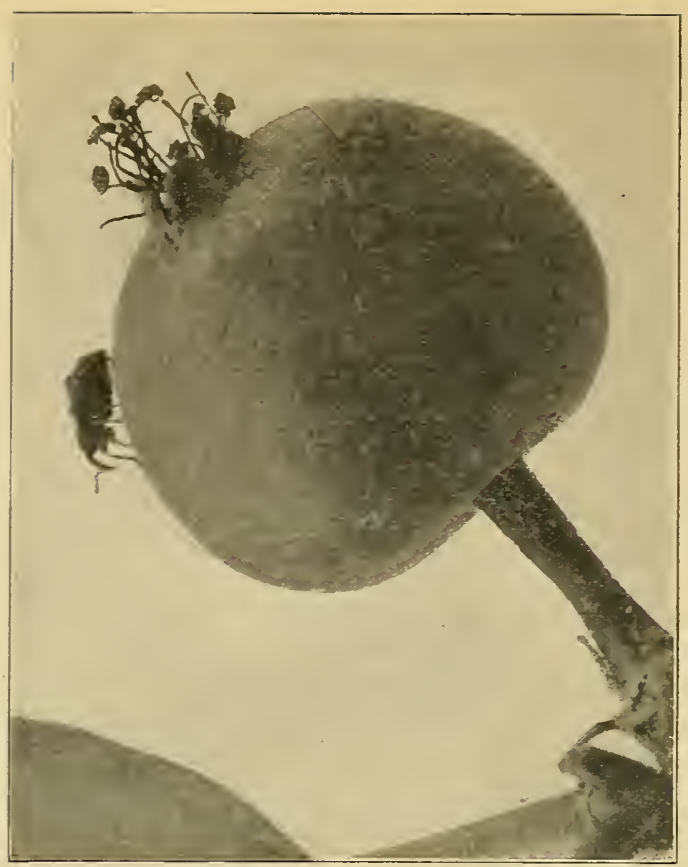

Plum Cureulio. Enlarged.

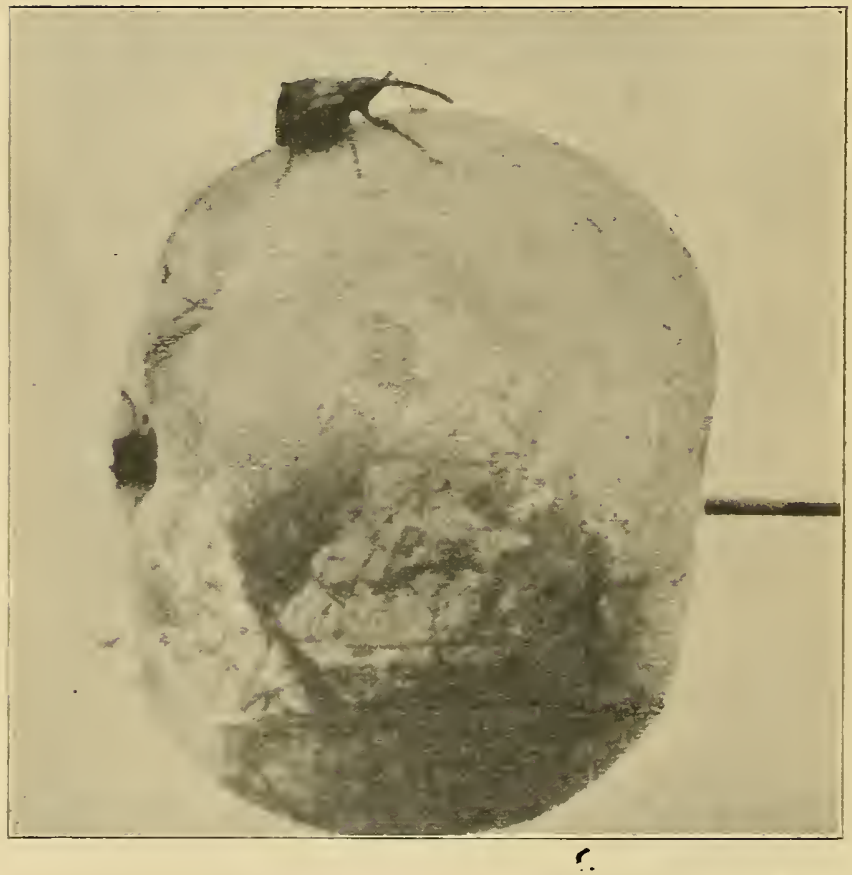

Apple Curculio. Enlarged. 


\title{
THREE SNOUT BEETLES THAT ATTACK APPLES
}

\author{
Fred. E. Brooks
}

INTRODUCTION.

For several years knotty and wormy fruits have composed far too large a proportion of the apple crop in many parts of this State. Where spraying has not been practiced, sound fruits have often been the exception rather than the rule and in many cases almost the entire crop has been next to worthless. This condition has been due largely to the attacks of insects which took place during the growth of the apples on the trees. The insects responsible for most of the worm-holes, scars and other malformations of the fruit are two species of small moths, known as the codling moth and lesser apple worm and three species of snout beetles. The injuries done by these five species are supplemented to some extent by the work of larger caterpillars, wasps and other insects but the bulk of the trouble is due usually to the first-mentioned species.

The codling moth will be considered in another bulletin of this station while this paper will deal with the three snout beetles, two of which are familar under the names "plum curculio" and "apple curculio" and the third, which is not so well known, and which may be called the apple weevil.

It is hoped that this bulletin may aid the fruit grower to a clearer understanding of the habits of these insects and to a better knowledge of the possibilities of holding them in check in the orchard. Such a knowledge should assist in extending the practice of spraying which, at present, is our surest and most practicable method of destroying these pests.

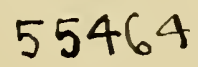


The writer wishes to explain that in describing the habits and life histories of the apple curculio, and, to some extent also, those of the plum curculio, he has drawn freely from the writings of other entomologists.

\section{THE PLUN CURCULIO}

\section{(Conotrachelus nenuphar Hbst.)}

The plum curculio is a snout beetle about one-fifth of an inch long. Its color is a mixture of black, brown and white, with the darker shades greatly predominating. On the back are several prominent humps which give the insect a roughened appearace and make it difficult to distinguish while on the tree from the bark or from a dry bud. It is armed with a curved snout one-third as long as the body.

\section{DISTRIBUTION AND HABITS OF THE BEETLE.}

The insect is a native of this country and is distributed over practically all the United States east of the Rocky Mountains. Before orchards were planted within its range it undoubtedly fed and bred on wild plums, crab apples. and hawthorns but with the settlement of the country it turned its attention more to cultivated fruits, although it continues to breed on the wild, native varieties. It attacks plums, peaches, nectarines, apricots, cherries, apples, crab apples, pears, quinces and hawthorns and has even been reported as breeding on persimmons. On account of the usual abundance of the insect and the great variety of valuable fruits which it attacks, there is little doubt but that it has been rightfully designated as the most destructive of all the insect enemies of the orchardist in this section of the country.

It injures the fruit by puncturing holes through the skin with its snout both for the purpose of feeding and egg-laying. The feeding punctures may be made in apples at almost any time during the summer but the egg punctures are made mostly while the apples are small. These wounds, and the subsequent 

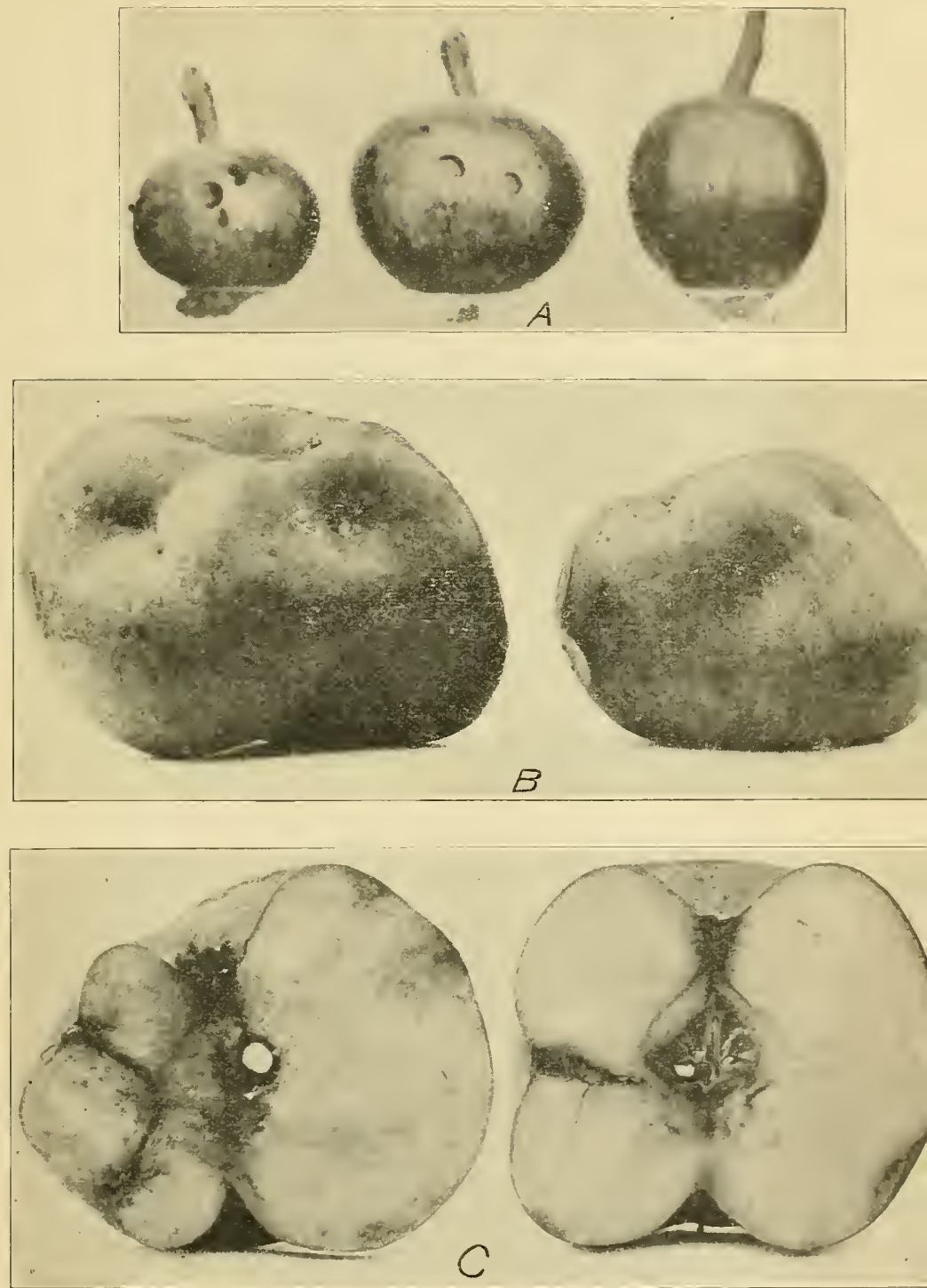

Photo by W. Fi. RUMSEY

A, two apples on left showing egg punctures of Plum Cureulio. one on right showing punctures of Apple Weevil.

B, depressions in surface of mature apples resulting from womnds made by Plum Cureulio.

C, sections of apple showing dark lines in flesh where larvae of Plum Cureulio have fed. 

feeding of the larvae which hateh from the eggs, cause the fruit to become dwarfed in size, lop-sided, knotty and otherwise misshapen.

\section{INJURIES IN WEST VIRGINIA.}

For several years the plum curculio has been very abundant in this State and was notably destructive to apples in the past spring and summer of 1909. By the first of June the apples in many unsprayed orchards showed the marks of the curculio in practically every fruit. Some early ripening varieties, such as Yellow Transparent and Early Harvest, were "stung" until the fruit was scarcely recognizable. On June $23 r^{\text {rd }}$ the writer counted the egg punctures in the fruit of three young York Imperial apple trees that had not been sprayed. The trees bore 210 apples which contained 1229 "stings," or an average of five to the apple. Only 10 of the fruits had escaped injury. The apples on these three trees did not appear to be injured more seriously than those borne by other trees in the same locality. Many complaints have recently come to the Experiment Station from various parts of the State in regard to injuries to apple by this insect.

\section{LIFE CYCLE.}

In the spring, a little before apple trees are in bloom, the heetles leave their hibernating quarters and seek the trees. At this time they feed rather sparingly on the expanding buds and young leaves while at the same time mating is in progress. Plums and cherries are usually the first fruits attacked but when apples are no larger than peas they begin to receive both egg punctures and feeding punctures. Egg-laying goes on rapidly through May and June but after the first of July, as the old beetles die off, oviposition practically ceases. The eggs hatch in four or five days and the small, white larvae, or "worms," when they develop normally, feed on the fruit for from 15 to 20 days and then leave their food and enter the ground. A short distance below the surface the lárva hollows out a small cell in the earth in which it transforms to a pupa and later changes to a 
beetle. The insects remain in the earth for a total period of about a month and then emerge, as beetles, and resort to the trees. During the remaining days of warm weather the young beetles live on the trees and often injure the fruit with their feeding punctures but do not produce eggs the first season. With the approach of cold weather they leave the trees and hibernate. The following spring they emerge from their winter quarters, lay their quota of eggs and after the succeeding generation has been provided for by this means, they die.

\section{DETAILS OF LIFE HISTORY AND HABITS.}

The Egg and Oviposition.-The minute egg of the plum curculio is oval in shape and, when first laid, is pearly white but it soon changes to a dingy, yellowish color. It is laid in a little pocket beneath the skin of the fruit which the female fashions with her snout. After the egg is deposited in the pocket the beetle, beginning at the puncture already made through the skin, cuts a crescent-shaped mark partly surrounding the egg. The crescent marks are very conspicuous on smoothskinned fruits and may be found usually in great abundance by examining bearing apple or plum trees in May or June.

The number of eggs that one female produces has been found by different entomologists to vary greatly, ranging from less than a hundred to 560 in one case. It is a safe estimate that the average individual produces 200 eggs. The eggs hatch in from three to seven days according to temperature.

The Larva.-In stone fruits, such as peach and plum, the larvae feed until full grown and then leave the fruit and enter the ground to a depth of one or two inches where they transform to pupae and a little later to adult insects. In apples, for some reason that does not appear to have been fully explained, the larvae are not able to reach full growth except when the infested fruit drops from the tree or stops growing soon after the larvae begin to feed. When the young curculio undertakes to develop within a vigorously growing apple it may feed for several days, 
boring its way from the skin toward the core, but it usually dies before the larval stage is half completed.

Many of the wounds made by the beetle are outgrown so that they can scarcely be seen in the ripe fruit. Frequently, however, the burrows made by the larvae show in the mature apples as dark-colored lines of hardened tissue having a bitter taste. On the surface of the fruit the outer ends of these lines are usually marked by scars with sunken, and often rusty areas about them. In the apples that drop the larvae develop normally, and, as many of the infested fruits fall to the ground, there would be an abundance of the beetles produced to perpetuate the species even though there were no host plants but the apple.

The Pupa.-The pupa is a delicate, white object, intermediate between the larva and the beetle, that occupies a cell in the ground, usually within two inches of the surface.

The Beetle.-The beetles mature and continue to emerge from the ground during quite a long period in the summer. After coming out, they are at first somewhat sluggish but they soon begin to feed on foliage and ungathered fruit. In apples they often make cavities of considerable size by repeatedly visiting one feeding place. The injury done to the fruit in this way is quite serious, since such wounds, whether small or large, disfigure the fruit and serve as centers for the spread of decay.

As already stated, the beetles do not lay eggs the first season but remain on the trees until warm weather is about over and then hide away near the ground under rubbish or in grass, or other material that will furnish protection, where they remain until the following spring.

The fact that injury is always worse at points in the orchard near to woods, or to accumulations of trash, indicates that the insects in the fall will go for some distance to seek such places to hibernate, and that they will resort to the most convenient trees when they emerge from hibermation in the spring. The 
fact also suggests that, where possible, such hiding places should not be allowed to exist in the vicinity of orchards.

\section{NATURAL ENEMIES.}

The plum curculio has a number of natural enemies which attack it during the different stages of its existence. In several parts of the country a minute, hymenopterous insect, known scientifically as Anaphes conotracheli Girault, has been found to live parasitically within the eggs and to destroy from 16 to 70 per cent of all that are produced. Another four-winged parasite of the curculios, Sigalphus curculionis Fitch, is quite common in West Virginia and has been reared repeatedly from the larvae of the plum curculio. The egg of this parasite is deposited in the fruit where the young curculio is feeding and the larva from this egg attacks the immature curculio and destroys it before it transform to a beetle. Ants, of several species, and the larvae of soldier beetles were observed in Upshur County, in 1908 , to kill many of the curculio larvae after they had left the fruit and were seeking places to pupate in the ground.

\section{METHODS OF CONTROL.}

The injuries done by the plum curculio are not so easily prevented as are those of some other insects, and yet there are a number of methods that ean be used against them with a very satisfactory measure of success. In dealing with the insect on apples by far the most effective means of preventing loss is spraying with one of the arsenical poisons, such as Paris green, or, preferably, arsenate of lead. Even where spraying is practiced, however, it is a good plan to use in connection with the operation some of the other measures suggested here, if the best possible results are to be obtained.

Jarring.-This method of dealing with the curculio consists of placing sheets of white cloth under the trees in the early morning and then jarring the insects from the branches to the sheets by striking the body of the tree a sharp blow with a padded mallet. The insects, being thus disturbed, "play pos- 
sum" and ean be eollected from the sheets by hand or by shaking them into some receptacle. The sheets may be stretched on light frames of wood so that they ean be moved conveniently and rapidly from tree to tree by several persons working together. Another method is to attach the sheets to a hoppershaped frame mounted on a two-wheeled eart made to push like a wheelbarrow. In making this eatcher a slit should be made in the front part of the sheet so that the body of the tree can enter, in pushing the outfit into place. A ean of kerosene may be arranged below an opening at the bottom of the hopper so as to catch the cureulios that roll down the inclined sides. This method of killing the insects is open to some objection from the fact that a great many lady-bugs and other benefieial species are destroyed along with the eureulios.

The jarring of the trees should be begun in the spring soon after the blossoms have disappeared and shonld be eontinued every morning for four or five weeks or for as long a time as many beetles are seeured. In some experiments conducted by the writer on plum trees, it was found profitable to continue the jarring for five weeks though when practiced every morning. for only three weeks deeidedly beneficial results were obtained.

This method of destroying the curculios is more practicable for plum and peach trees than for apple trees because of the faet that apple trees are often so large that it is a slow and laborious task to jar them effeetively.

Cultivation.-Cultivation of the soil under the trees during July and Angust breaks up the pupal cells and exposes the young eureulios to the light, which is destructive to them, and to the attaeks of predacious insects and birds. In this way many of them can be destroyed. In most of the apple orehards of West Virginia the trees are now being headed so low that it is impossible to eultivate directly beneath the branches which is neessary in order to destroy the young curculios by this method. However, the greater ease with which low-headed trees may be sprayed and the other advantages of this form of pruning probably mueh more than offset this one disadvantage. 
Destroying Fallen Fruit.-If the fruits of any of the varieties in which the curculio breeds are collected from the ground in June and July and burned or fed to hogs many of the insects will be destroyed. Infested fruits usually drop several days before the larvae within them are full grown and by disposing of the drops the number of curculios that would compose the succeeding generation can be greatly curtailed.

Spraying.-The same poisons that are used as sprays on apple trees to destroy the codling moth are the ones most effective against the plum curculio. In dealing with either insect the first spray should be applied as soon after the blossoms have disappeared as possible. The spray should consist of from one to three pounds of arsenate of lead to fifty gallons of water, or, where Bordeaux mixture is used, the same amount of arsenate of lead to fifty gallons of the mixture. This method of dealing with the plum curculio has given good results in many different states and is a well-tried and safe remedy.

In some experiments conducted by this station in Berkeley and Upshur counties, in 1909, it was found that one pound of arsenate of lead to fifty gallons of water, when applied to the trees just after the petals had fallen through a Bordeaux nozzle at a pressure of from 180 to 250 pounds, gave practically the same results against the curculio as the stronger mist sprays when applied oftener at a lower pressure.

By spraying in the two ways mentioned above, Mr. W. E. Rumsey, of the Experiment Station, in an orchard in Berkeley county, reduced the curculio punctures in apples with a single high-pressure spray from 32 per cent to 12.5 per cent and with four mist sprays from 32 per cent to 13.9 per cent.

The writer, after using the two methods of spraying as described above, in an orchard of fifty young York Imperial apple trees in Upshur county, found that on June 23rd, after practically all the curculio eggs had been deposited, 95.4 per cent of the unsprayed apples contained egg punctures, 41 per cent of those treated but once, with the high-pressure spray, contained eggs punctures and 40 per cent of those sprayed four 


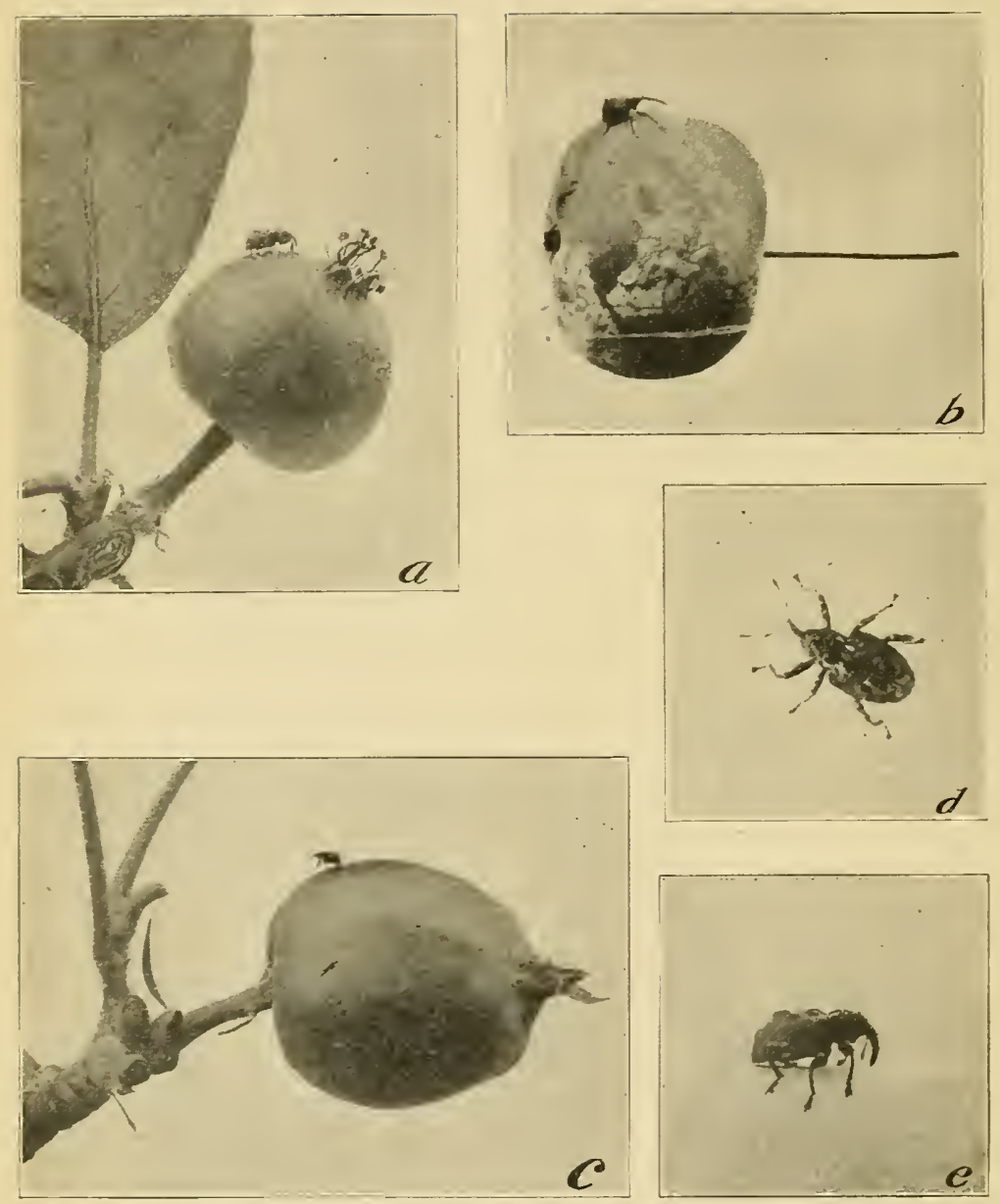

a, Plum Curculio; b, Apple Curculio; c, Apple Weevil; d, e, Plum Curculios.

$a, b$ and $c$, natural size; $d$ and e, enlarged. 
times with the mist sprays contained egg punctures. This experiment showed an advantage of the sprayed over the unsprayed fruit of about 55 per cent.

A similar saving of the fruit by spraying has been accomplished in many other tests and experiments in this state and in other states.

\section{THE APPLE CURCULIO. \\ (Anthonomus quadrigibbus Say.)}

\section{INTRODUCTION.}

This insect has been confused often with the plum eurculio but in reality it is quite distinct from that species in both appearance and habits. The apple curculio is more reddish-brown in color, the form is more robust and on the back are four prominent humps, the front two of which are much larger than any of the humps on the back of the plum curculio. The snout of the apple curculio is almost as long as the rest of the body, or three times the length of that of the other species. This snout is carried projecting forward, instead of hanging down like an elephant's trunk, as is the case with the plum curculio.

In attacking the fruit the apple curculio bores through the skin, in a manner similar to that of the other species, but after the puncture is completed and the egg laid, only an indistinct speck is left on the surface to mark the place of injury whereas the plum curculio makes the conspicuous crescent-shaped mark. A glance at the insects or at their work is sufficient to enable any one, who is at all well acquainted with the species, to distinguish between the two. The apple curculio is much less abundant and destructive in West Virginia than the other species.

HISTORY AND DISTRIBUTION.

The apple curculio is a native American species of wide distribution. It has been reported from Connecticut and Ontario south to North Carolina and westward as far as New 
Mexico. It seems to have been more troublesome in Missouri, Illinois and other mid-western states than elsewhere.

The species was named and described by Thomas Say, in the year 1831. Its life history was worked out in Missouri by C. V. Riley, in 1870 , and more thoroughly, by Prof. Charles S. Crandall, of the Illinois Experiment Station, in 1904.

Its original food was the fruit of the thorn and wild crab but as the settlement of the country has provided it with opportunities to attack cultivated apples it has turned its attention from time to time to these fruits and become a pest of considerable importance.

The writer has found this curculio on apple, plum and wild crab at French Creek, Upshur county, and on wild crab at Seebert, Pocahontas county. In both cases on the crab it was present in considerable numbers. While, to our knowledge, it has never been a pest of serious consequence to the apple in West Virginia, yet, the fact that it breeds here, quite probably in considerable numbers in many parts of the state, together with the fact that it seems to be forming a liking for cultivated apples, should lead the fruit grower to regard it with suspicion and to do what he can to prevent its rapid multiplication.

\section{FOOD PLANTS.}

The fruits that the apple curculio has been recorded as attacking are the hawthorn, wild crab, haw, wild cherry, quince, pear and apple. Prof. W. E. Britton reports that the beetles. in one case, injured peach trees in Connecticut by puncturing the twigs full of holes.

\section{LIFE HISTORY.}

According to Riley and Crandall, the life history of the apple curculio is as follows. The beetles emerge from hibernation early in the spring and soon after the blossoms disappear from the trees, begin laying eggs in the young fruit. Egg-laying extends over a period of about sixty days and one female may produce something over 100 eggs but the average is only about 
65 for each individual. The eggs hatch in about five days and the larvae therefrom feed on the flesh of the apple for about twenty days, when they reach full growth and transform to pupae within the fruit. After remaining in the pupa form for about a week they change to beetles and soon after leave the fruit.

Unlike the plum curculio, the young beetles of this species do not appear to injure apples by feeding on them during the late summer and fall after their emergence. According to Crandall, by the first of August most of the beetles have disappeared from the trees and after that date are found near the ground in grass beds and among fallen leaves. Of about twenty. five specimens which the writer bred from crab apples at French Creek more than half the number did not leave the fruit until after August 10th. It appears from this that if the young beetles go to the trees after they emerge from the fruit they may be found on the trees somewhat later in the season here than in Illinois.

APPEARANCE AND HABITS OF THE LARVA.

The larva of the apple curculio is a wrinkled, footless, dingy white grub which, when full grown, is nearly half an inch in length. Some of the body segments in front of the middle are greatly enlarged on the back which gives the larva a hump-backed appearance and prevents it from straighteninir out as the larva of the plum curculio is able to do. The head is yellowish brown with the jaws dark brown. In feeding it ejects from the fruit a greater quantity of excrement than is thrown out by the larva of the plum curculio. The ejected castings are reddish brown in color and often adhere to the skin of the fruit in conspicuous masses like those seen about the burrows of the codling worm.

HOW THE FRUIT IS INJURED.

Injury is done to the fruit by the beetles which drill pits into the flesh for feeding and for the reception of eggs, and by 
the larvae which feed and undergo their full development within the fruit.

The feeding punctures made by the beetles extend directly into the fruit to a depth of .08 inch. The egg punctures are similar but are considerably enlarged at the inner end where the egg is located. After the female has deposited her egg in a puncture she seals the opening through the skin with a bit of excrement which becomes hard when dry and probably excludes enemies that would attack the egg.

\section{NATURAL ENEMIES.}

The writer reared one hymenopterous parasite from wild crab apples infested with larvae of the apple curculio which were collected at French Creek. The adult insect appeared in the breeding jar in which the crab apples were kept on August 18, 1909. Through the kindness of Dr. L. O. Howard, it was determined for me by Mr. H. L. Viereck, of the Bureau of Entomology, as Pristomeridia agilis (Cress.)

\section{METHODS OF CONTROL.}

Where the apple curculio becomes troublesome care should be taken that no thickets of wild crab or hawthorn are allowed to remain as breeding places near the orchards. Such thickets may produce thousands of the beetles and when the wild fruit becomes insufficient for the great number of beetles they may seek places to feed and oviposit in cultivated orchards.

The jarring method, as recommended for the plum curculio, is effective when used against this species. Spraying with poisons is likely to be beneficial but it is probable that not as many of the beetles will be killed by the opration, as in the case of the plum curculio, for the reason that in feeding they consume little of the exposeed surface to which the poison is applied. 


\section{.}



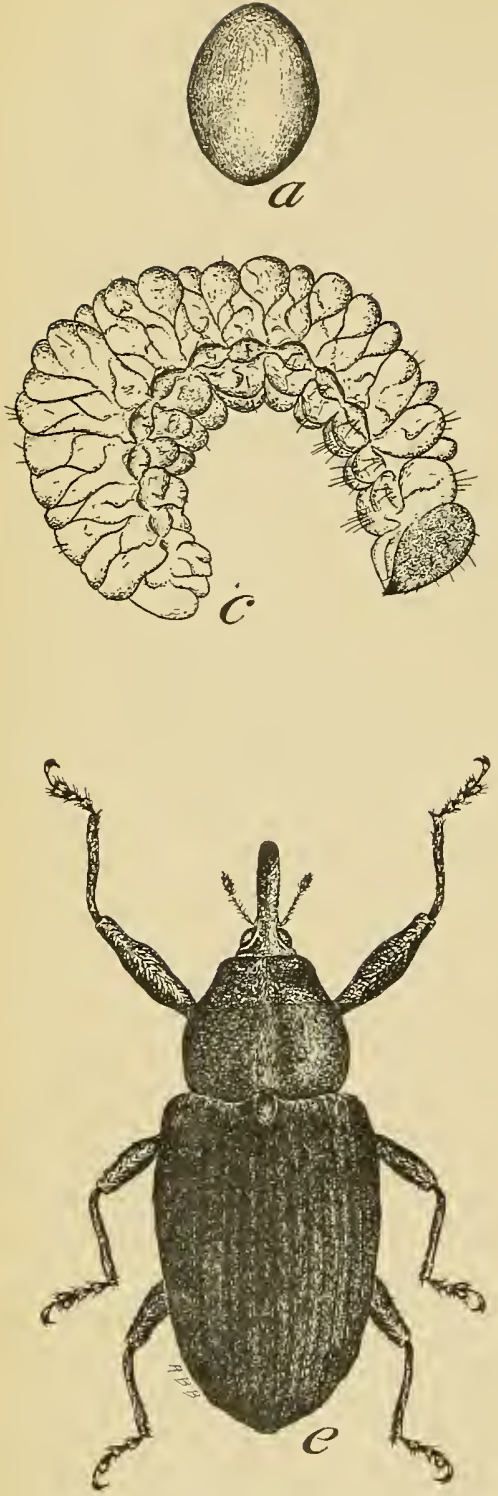
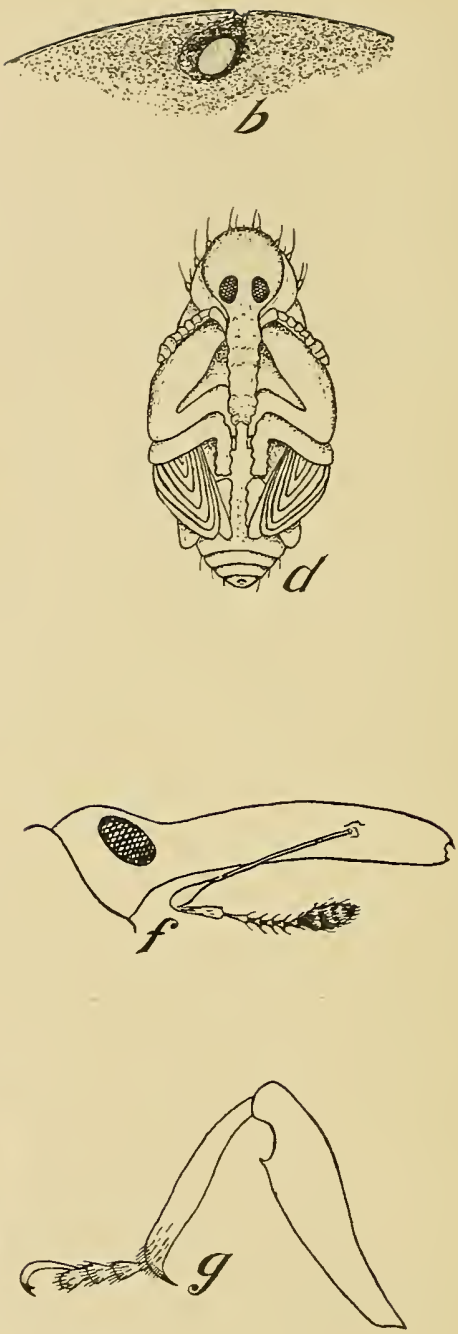

Apple Weevil, Pseudanthonomus crataegi Walsh. a, egg; b, location of egg in flesh of apple; c, larva; d, pupa; e, adult; f, snout and antenna; g, leg. All greatly enlarged. Drawings by A. B. Brooks. 


\section{THE APPLE WEEVIL.}

\section{(Pseudanthonomus crataegi Walsh.)}

In making observations on the extent of injury that was being done to apples by the plum and apple cureulios, during the spring and summer of 1909 , it was noticed that another small snout beetle was present on the trees and was doing considerable damage to the young fruit. The insect was not recognized at first and specimens were forwarded to the specialists in Wash. ington who identified them as belonging to the species whose technical name is given above.

The species does not appear to have attracted attention previously as an enemy of apples but according to observations made by the writer the habit of breeding in this fruit seems so well fixed that the common name "apple weevil" is suggested as being suitable.

The first instance that came under our notice, in which apples were attacked by this insect, was in June, 1907, when Mr. W. E. Rumsey, of this department, saw one of the beetles lay its egg in an apple growing on the Experiment Station Farm at Morgantown. In the spring of $1909 \mathrm{Mr}$. Rumsey also saw numerous punctures in young apples in Berkeley county which he attributed to this species. At French Creek, in Upshur county, the beetles were abundant on apple trees during the past summer, (1909), and in some cases almost every fruit on unsprayed trees showed the punctures of the insect.

HISTORICAL.

Very little has been written in regard to the feeding habits of this insect. It was bred from Cecidomyid galls on crataegus (hawthorn) by Benjamine Walsh, in Illinois, and was described and named by him in 1866. There are a few brief records of the adults having been collected from flowers where they may have been feeding on pollen. LeConte gives its distribution as Middle, Western and Sonthern States, to Texas. (Rhynchophora of N. A. p. 205.) A. D. Hopkins collected the heetle in Tonongalia county, W. Va., in June, 1893. 
APPEARANCE AND HABITS OF THE BEETLES.

The apple weevil is a small, elongate beetle, measuring onetenth of an inch in length, exclusive of the snout, which is a little less than half as long as the body. The snout and prothorax are finely and densely punctured and the wing covers deeply striated. The beetle is a uniform sepia brown throughout with a sparce covering of short yellowish hairs, particularly noticable along the upper part of the prothorax where they form a more or less distinct, longitudinal, dorsal line. This species may be distinguished very readily from either of the curculios described in this paper by its much smaller size, lighter and browner color and the absence of humps on the back.

The beetles emerge from hibernation early in the spring and toward the last of May begin to lay eggs in young apples. On May 28th the writer saw the beetles engaged in oviposition and found the eggs abundant in two varieties of sweet apples and somewhat less abundant in several varieties of more acid fruits in a neglected apple orchard at French Creek. In this orchard egg-laying continued until near the last of June, and soon after that time all the beetles of the over-wintering generation disappeared and oviposition ceased. In addition to observations made in the orchard a number of beetles. were kept in breeding jars, as nearly as possible in a natural temperature, and their habits noted. The last egg obtained from the beetles in the jars was laid on .June 24th and the last of the beetles dier on July 8 th.

Early in July the beetles of the second generation began to appear. The first adult of this generation was seen to emerge, with slight assistance, from an infested apple on July 7 th, one day hefore the last of the old generation passed away. By the 25th of July beetles from the early laid eggs were appearing in the breeding jars in considerable numbers though the last individual of them did not leave the apple until August 30th. The period during which the beetles were emerging seemed to be considerably longer than the period of oviposition. This was 
due to the great variation in the length of time required by the different individuals to complete their transformation. A difference of several weeks, in this respect, was noticed in the individuals which developed from eggs laid by a single female during one day in one apple.

BEHAVIOR OF THE YOUNG BEETLES.

The young beetles after appearing in July and August spend the remaining portion of warm weather about the trees and when cool weather approaches they hibernate, presumably beneath scales of bark and in other sheltered places in and near the orchards. No evidence could be found that these young beetles lay eggs the first season. Twenty-five such beetles were kept in confinement from about the first of August until the first of November. These beetles were supplied with apples at all times but there was no sign of oviposition. A close watch also of the insects on the trees aided in the conclusion that there is but one generation produced annually.

HOW THE BEETLES FEED.

As has been stated already, the beetles feed on the young fruit. This they do by making minute punctures through the skin and then eating all the flesh of the apple that can be reached with the snout through the opening. As the apples increase in size the individuals of both generations feed in the open wounds made by larger insects. They also feed on decayed fruit. A limited portion of their food is obtained from the leaves by scraping fragments of the tissue from the upper surface. The beetles were seen engaged in this manner of feeding on the trees and those kept in confinement riddled the apple leaves with which they were supplied with small holes. From an economic standpoint, this habit of attacking the leaves is important for it brings the species more readily within the reach of arsenical poisons.

\section{OTHER HABITS OF INTEREST.}

When the beetles are disturbed by the shaking of the branch on which they are resting or the sudden and near approach of 
some object that alarms them, they have a habit of raising the front part of the body by extending the forelegs and at the same time elevating the snout so that it points directly forward instead of hanging down. After assuming this pose they will sometimes remain rigid and motionless for several minutes. It usually requires a somewhat violent jar to dislodge them from their position on a branch.

\section{NATURE OF INJURY.}

The beetles make two kinds of wounds in the fruit. One of these is made by the female to receive the egg and the other is made by both sexes in feeding. Both forms of wounds are in the shape of minute punctures through the skin which extend to a depth of about .04 of an inch into the flesh of the apple. On the surface of the fruit the average sized opening is slightly less than .01 of an inch across but beneath the skin it is enlarged considerably. Externally the egg punctures may be distinguished from the others by the small mass of glue-like excrement with which the opening through the skin is sealed. The feeding punctures are left open. The wounds are so small that in making a careful examination the aid of a magnifying lens is necessary.

The fruit may be attacked at any point on the surface but the punctures are found usually most numerous about the calyx and stem. So far as could be determined, nearly all the wounds that are made in sound fruit occur when the apples are quite small. The feeding punctures, in cases where decay does not set in, usually heal over so that they show only as minute scars in the ripe fruit. The same is true of the egg punctures where the eggs fail to hatch or where the larvae die soon after beginning to feed, as is often the case. The wounds made by the weevils are sometimes found and enlarged by plum curculios and possibly by other insects that feed on apples. The wounds also form centers for the spread of decay.

The larvae that hatch from the eggs feed on the fruit, forming tortuous tunnels through the flesh, or, more often, 
make large and irregularly shaped feeding chambers about the core. The excavations are filled with dark-colored, granular excrement scarcely any of which is cast to the surface of the fruit. The larvae are not able to reach full growth within apples that hang to the branch and continue to grow vigorously. They will live for a few days in such fruit, feeding about the chamber in which they hatched, but die after a brief effort to subsist on the juicy, growing fruit. In apples that cease to grow, whether they fall to the ground or remain as mummies hanging to the branches, the larvae live, reach full growth and then pupate within the fruit.

It was not determined whether the wounds of the apple weevil alone are sufficient to cause the apple to drop or whether the species is dependent upon assistance from fungous diseases and other insects in causing the apples to come to a condition which suits their requirements in reaching full development.

\section{THE EGG AND OVIPOSITION.}

The egg is yellowish white, oval-oblong in shape, .015 inch wide and .020 inch long. All the eggs observed, with the exception of two, were deposited in punctures excavated from young apples by the female beetle. The two exceptions were cases where the eggs were laid in the stems of apples. After the egg is laid the beetle ejects a small quantity of excrement which is plastered over the opening in the skin, thus effectually sealing the egg chamber. This is evidently done to protect the egg from predacious insects or mites. The time required by the beetle to make the puncture, deposit the egg and seal the hole was observed in one case to be 13 minutes.

Of about a dozen eggs that were laid on June 1st, all hatehed on June 5th. In numerous other cases the period of incubation was found to be either four or five days. The exact number of eggs that one individual will produce was not determined. A record was secured, however, from two females that were caught a few days after oviposition was known to be in progress on the trees. The females, each accompanied by a male, were caught 
on MIay 29th and the pairs confined separately in glass jars. Fresh apples were placed in the jars each morning and the old ones removed and the eggs counted. One of the females lived until June 25th, a period of 26 days, and laid 119 eggs. The other lived until June 30th, a period of 31 days, and laid 66 eggs. The greatest number laid by one beetle during any one day was 10. Egg-laying by the beetles on the trees seemed to he the most rapid during the period from May 25th to June 15th.

\section{THE LARVA.}

The larva is a robust, wrinkled, footless grub about oneeighth of an inch in length. Its color is yellowish white but when feeding on decayed apples the contents of its digestive organs give it a darker appearance. The head is light brown, the jaws dark brown to black. The body is sparsely covered with short hairs, more numerous near the head. From the head the diameter of the body increases gradually to the eighth segment and then decreases more rapidly to the posterior extremity. The larva is always found in a curved or curled-up position and when removed from the apple it moves awkwardly on its side or back and is unable to straighten out and crawl on its belly like the larva of the plum curculio. The larval period was found to vary greatly in length ranging from 18 days, in one case, to 53 days in another. Its average duration seemed to be about 30 days. The larvae are able to subsist on apples that are almost any condition of soundness or decay, except those that are growing vigorously on the tree. Sound, fallen apples, those that are soft and slimy with decay and those that are shriveled and dried until they are almost as hard as wood seem to afford the insect acceptable food. Apparently, the condition of the apple in which the insect was feeding did not effect greatly the duration of the larval stage.

In many eases in the orchard from three to five larvae were found developing in one apple and in the laboratory as many as twenty reached the beetle stage within a single fruit. 
'THE PUPA.

The larvae change to delicate, white pupae in cells which they make in the tissue of the apple. These cells are just large enough to accommodate the body of the insect and may be located at any place within the apple from near the skin to the core.

The exact length of the pupal stage was observed in only four individuals. In each of the four cases it was 8 days. The development of other individuals that were watched less closely indicated that in some cases the stage may be of longer duration, though the exact time was not noted. It is probable, also, that with some it is less than 8 days. This was indicated in the instance of one precocious individual which accomplished the entire transformation from the laying of the egg to the adult insect in 30 days.

NATURAL ENEMIES.

One parasitic insect was reared from the apple weevil in the manner described as follows: On July 7 th an apple was cut open that contained a full-grown weevil larva. Adhering closely to the side of the larva was another minute, white larva that was recognized as a parasite. The two were carefully removed into a breeding bottle and kept under observation. The parasite developed very rapidly in size and two days after being placed in the bottle it had killed and almost entirely devoured its host. When its food was gone it constructed a delicate cocoon of white silk beside the shriveled skin of the insect it had destroyed. Within this cocoon it changed to a pupa on July 13th and on July 20th it emerged from the cocoon as a small, yellowishbrown, four-winged insect. The insect was sent to Washington where it was determined by Mr. H. L. Viereck as Bracon anthonomi Ashm., a species that was reared in 1892 from the strawberry weevil, Anthonomus signatus, by Dr. F. H. Chittenden, of the U. S. Department of Agriculture. 
MEANS OF CONTROL.

Destroying Fallen Fruit.-The weevils usually remain in fallen apples for a week or more after they drop and any method of destroying the young apples that accumulate on the ground early in the season will dispose of many of the insects.

Spraying.-A part of the orchard at French Creek, in which the investigations described in this bulletin were carried on, was sprayed with arsenate of lead to control the codling moth and plum curculio. No apple weevils were found on the sprayed trees and the fruit, which was observed closely, showed no injury from this species. The habit which the beetles have of feeding on apple foliage makes it clear that they are within the reach of poisonous sprays and explains their apparent ahsence on the sprayed portion of the orchard. There is little doubt that many of the beetles are killed by swallowing the poison that adheres to the leaves of sprayed trees.

Jarring. - The beetles can be caught with sheets in the manner described for dealing with the plum and apple curculios, but, as has been stated already, the jarring of large apple trees is not often practicable. 




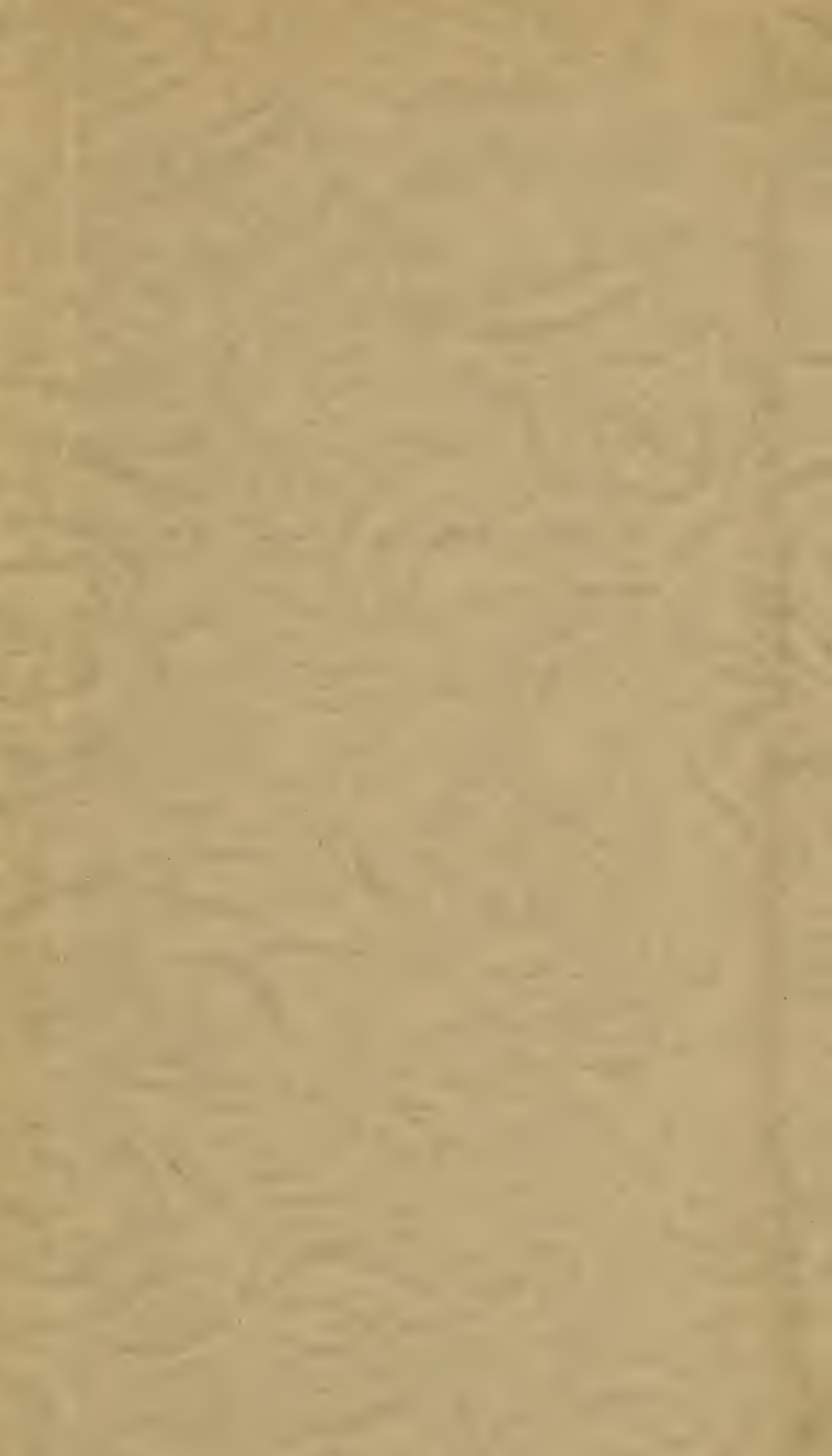


